\title{
Making Dioramas of Women Scientists Help Elementary Students Recognize Their Contributions
}

\author{
Jolene K. Teske1, Phyllis Gray¹, Julie L. Klein'1, Audrey C. Rule ${ }^{1,2}$ \\ ${ }^{1}$ Department of Curriculum and Instruction, University of Northern lowa, Cedar Falls, USA \\ ${ }^{2}$ Center for Educational Transformation, University of Northern lowa, Cedar Falls, USA \\ Email: audrey.rule@uni.edu
}

Received 23 September 2014; revised 20 October 2014; accepted 12 November 2014

Copyright (C) 2014 by authors and Scientific Research Publishing Inc.

This work is licensed under the Creative Commons Attribution International License (CC BY).

http://creativecommons.org/licenses/by/4.0/

(c) (i) Open Access

\begin{abstract}
The STEM movement encourages girls to consider careers in science; however, for success, common misconceptions and biases need to be dispelled, while females' spatial thinking skills are developed. All students, both girls and boys, need exposure to the accomplishments of women scientists to appreciate their contributions and to envision females as successful scientists. This oneweek study conducted during a summer day camp examined upper elementary student (n = 15; 7 females, 8 males) attitudes toward science, women in science, and the possibility of a science career before and after participation in learning about diverse accomplished women scientists and making a diorama showcasing the professional work and caring actions of one of the scientists. The efficacy of this project for upper elementary students, conducted during a summer day camp, is supported by pretest-posttest data and attitude surveys. The five-day class showed positive changes in student plans for a career in science and improved attitudes toward the importance of females becoming scientists. Directions for constructing dioramas, examples of student-made work, and creative scenes made with given craft items are provided.
\end{abstract}

\section{Keywords}

Student Attitudes toward Science, Women in Science, Dioramas, Spatial Skills, Science Careers

\section{Introduction and Background}

\subsection{Fewer Girls Aspire to STEM Careers}

A study undertaken by the American Association of University Women (Hill, Corbett, \& St. Rose, 2010) ex-

How to cite this paper: Teske, J. K., Gray, P., Klein, J. L., \& Rule, A. C. (2014). Making Dioramas of Women Scientists Help Elementary Students Recognize Their Contributions. Creative Education, 5, 1984-2002. 
plored the reasons why so few women have careers in the science, technology, engineering, and mathematics (STEM) fields. Although both female and male students study mathematics and science in roughly equal numbers with equal achievement during their kindergarten through grade 12 years and are similarly prepared for science and engineering majors in college (Shettle et al., 2007), fewer women pursue these majors (National Science Foundation, 2009). At college graduation, men outnumber women in almost all science and engineering fields with women earning only $20 \%$ of the degrees in physics, engineering, and computer science (National Science Foundation, Division of Science Resources Statistics, 2008, data from Table 11). At the graduate education level, the university faculty level (Di Fabio, Brandi, \& Frehill, 2008), and in the industrial workplace (Hewlett et al., 2008; Simard et al., 2008), women's science and engineering participation declines further.

The reasons why more females don't enter STEM fields are generally cultural (Hill, Corbett, \& St. Rose, 2010). Current cultural structures include family differences in career expectations for daughters compared to sons (Leaper \& Brown, 2008) and the lack of female science role models in schools and the media (Bettinger \& Long, 2005; Fouad, Hackett, Smith, Kantamneni, Fitzpatrick, Haag, \& Spencer, 2010). Negative stereotypes about girls' abilities to perform in mathematics and science still abound, lowering girls' aspirations for these career areas (Hill, Corbett, \& St. Rose, 2010). A "growth mindset” in which a person believes one can learn new skills and improve is needed for girls to envision themselves as working hard, gaining competence, and eventually succeeding at challenging tasks (Dweck, 2006, 2008). Girls' internalized standards for self-performance in STEM subjects are higher than those of boys, with girls telling themselves they need to perform at exceptional levels to succeed (Correll, 2004). Additionally, spatial ability has been identified as a necessary foundational skill area for success in the STEM fields (Downs \& DeSouza, 2006).

Spatial ability is one area, though, in which men and boys currently outperform females (Sorby \& Baartmans, 2000; Voyer, Voyer, \& Bryden, 1995). However, females can quickly catch up if given the opportunity to exercise those skills (Sorby, 2009). Sorby, a researcher who has been examining male-female spatial ability and ways to improve spatial skills for many years, "sees well-developed spatial skills as important for creating confidence in one's ability to succeed in math and science courses and ultimately in a STEM career, because spatial skills are needed to interpret diagrams and drawings in math and science textbooks as early as elementary school" (Hill, Corbett, \& St. Rose, 2010: p. 56).

Other cultural biases affect girls' entry into and persistence in STEM fields. A study of high school students' attitudes toward science careers (Miller, Blessing, \& Swartz, 2006) found that females considering a science career were more interested than males in the people-oriented aspects of that major. The notion, often subconscious (Nosek, Banaji, \& Greenwald, 2002), that STEM fields are "masculine” impacts girls' decisions about careers. Many people judge women in the STEM fields as less competent than men until they have shown themselves to be clearly successful, at which point they are often viewed as less likable (Heilman et al., 2004; Archer, DeWitt, Osborne, Dillon, Willis, \& Wong, 2012). A way that a successful woman in a predominantly male field could maintain being positively viewed by colleagues was to strongly exhibit traits of being understanding, caring, and compassionate (Heilman \& Okimoto, 2007). Early instruction dispelling these stereotypes and biases can positively affect the number of females who choose and complete careers in the STEM fields. Exposing elementary students to females' achievement in STEM areas can 'affect girls' performance, how they judge their performance, and their aspirations” (Hill, Corbett, \& St. Rose, 2010: p. 90).

\subsection{The Women Scientists Diorama Project}

This model-construction and science learning activity project focused on changing boys' and girls' ideas about women's contributions to science by exploring the lives and work of eight notable women scientists through making a three-dimensional diorama. The investigators asked, "How will making a diorama of a woman scientist's life and work, and hearing about the lives of other female scientists through electronic slide presentations affect elementary student attitudes toward women in science and a science career in general?” The study took place during a week-long summer day camp in which 15 students entering grades 4, 5, and 6 attended the women scientist diorama class for approximately 45 minutes each day.

The diorama-creation activities were designed to maximize positive impact on the elementary student participants in the following ways:

- Eight female scientists were highlighted to focus attention on women's proficiency and contributions to science. Contemporary or near contemporary women scientists were chosen, rather than historic women 
scientists such as Marie Curie, so that students would become familiar with modern role models. Two previous studies (Mead \& Métraux, 1957; The Research Business, 1994) indicated that most high school students were familiar only with famous men of science like Einstein, Bell, and Newton. The earlier study (Mead \& Métraux, 1957) recommended that science teachers focus more on tales of what scientists do in their daily work. The cultural significance of women scientists’ work was highlighted, as Munro and Elsom (2000) found that science teachers tend to emphasize the instrumental value of scientists' work to the advancement of science, causing students to surmise that science is only of value to scientists with little impact on everyday life.

- The diorama work presented many spatial problems such as: how to make a pop-out scene, how both the interior and exterior of a building could be portrayed in a diorama that opened like a book, arrangement of images, and making of miniature furnishings. This three-dimensional work supported development of spatial skills important to success in STEM fields (Root-Bernstein \& Root-Bernstein, 2013).

- Women scientists were chosen to present a racially diverse group of scientists working in different areas of science with a variety of scientific, personal, and social challenges. The number of minority students pursuing STEM careers is small, partly because these students have less access to advanced science and mathematics coursework in high school (Perna et al., 2009). Another reason minority students do not pursue STEM fields is the lack of a network of support leading to self-efficacy in science (Chemers, Zurbriggen, Syed, Goza, \& Bearman, 2011). Because many minorities are not aware of minority role models in science (Johnson \& Watson, 2005), we chose a diverse group of eight women scientists. Mary Leakey and Dorothy Crowfoot Hodgkin were White British women, Barbara McClintock was a White American; Lisa Perez Jackson and Patricia Bath are African Americans; Tolani Francisco and Joan Esnayra are Native Americans; Ellen Ochoa is a Hispanic American.

- The electronic slide show presentations designed by the teachers told about many aspects of each scientist and her work, including ways she was a caring person to counteract the stereotype that successful women in science are cold and uncaring (Heilman et al., 2004).

\subsection{Standards Addressed by the Women Scientists Diorama Project}

Many crosscutting concepts from the Next Generation Science Standards (Achieve Inc., 2013) were addressed by the women scientist diorama project. Table 1 presents these and describes how information provided to students about the women scientists supported the standards.

The Benchmarks for Science Literacy (American Association for the Advancement of Science, 1993), in discussing the "Scientific Enterprise, state "By the end of the $5^{\text {th }}$ grade, students should know that science is an adventure that people everywhere can take part in, as they have for many centuries" (p. 16), and, "By the end of $8^{\text {th }}$ grade, students should know that until recently, women and racial minorities, because of restrictions on their education and employment opportunities, were essentially left out of much of the formal work of the science establishment; the remarkable few who overcame those obstacles were even then likely to have their work disregarded by the science establishment” (p. 17).

The state in which this study took place, Iowa, has education standards for all grade levels (Iowa Department of Education, 2013). In the area of $21^{\text {st }}$ Century Skills, at the grade 3-5 level, the Iowa Core states: "Students will choose a career area that interests them, and produce a list of skills, habits, and duties that assure success in that career area." Learning about the lives of women scientists will enlighten students as to what they actually do in their jobs and the required skills and dispositions necessary for being scientists.

\section{Method}

\subsection{Participants}

This lesson sequence was conducted with a group of 15 elementary students ( 7 female, 8 male; 11 White, 2 Black, 2 Hispanic; 5 entering fourth grade, 6 entering fifth grade, and 4 entering sixth grade) during a daily 45-minute class at a weeklong summer day camp. This project was approved by the Human Subjects Committee of the overseeing university and the day camp directors. All participants and their parents provided written consent for data and photographs to be used in the study. 
Table 1. Crosscutting concepts from the $4^{\text {th }}$ and $5^{\text {th }}$ grade next generation science standards addressed by the women scientists diorama project.

Crosscutting concept
Connections to engineering, technology, and
applications of science.
Influence of science, engineering and technology on
society and the natural world.

People’s needs and wants change over time, as do their demands for new and improved technologies. (3-5-ETS1-1)

Engineers improve existing technologies or develop new ones to increase their benefits, decrease known risks, and meet societal demands. (3-5-ETS1-2)

Interdependence of science, engineering, and technology.

Knowledge of relevant scientific concepts and research findings is important in engineering.

Connections to nature of science

Science is a human endeavor.

Most scientists and engineers work in teams.

Science affects everyday life.

Scientific knowledge assumes an order and consistency in natural systems

Science assumes consistent patterns in natural systems.

\section{Patterns}

Similarities and differences in patterns can be used to sort and classify natural phenomena.

Similarities and differences in patterns can be used to sort and classify designed products.

Systems and system models

A system can be described in terms of its components and their interactions.

Cause and effect

Cause and effect relationships are routinely identified, tested, and used to explain change.

Scale, proportion, and quantity

Natural objects exist from the very small to the immensely large.

Energy and matter

Energy can be transferred in various ways between objects.
How concept addressed by the women scientist diorama project

Joan Esnayra founded the psychological service dog society to provide assistance to veterans and others with posttraumatic stress disorder and other mental issues.

Patricia Bath improved the technology of mechanically grinding away the clouded cornea to treat cataracts by inventing the Laserphaco probe, a faster, more accurate and less painful approach to cataract removal.

Astronaut Ellen Ochoa earned degrees in science and engineering, working on optical systems and robotics for the space program before becoming the director of the Johnson Space Center.

Barbara McClintock worked with a team of botanists from South America to determine the evolution of maize.

Lisa Perez Jackson observed the inequities of clean air and water for people in impoverished communities; therefore, she worked to develop environmental protection agency regulations.

All of the women scientists examined patterns in some way to solve the problems they encountered. For example, crystallographers study X-ray diffraction patterns to determine arrangement of atoms.

Dorothy Crowfoot Hodgkin examined X-ray diffraction patterns to determine the crystal structure of vitamin B-12 and over 100 other compounds.

Mary Leakey developed a classification system for the stone tools she excavated.

Veterinarian Tolani Francisco worked within the natural interactive system of cattle and bison to determine the transmission of infectious diseases.

Barbara McClintock conducted genetic experiments with corn, observing the colors of corn kernels to determine her Nobel Prize-winning model of jumping genes.

Many of the scientists used microscopes (micro scale) or X-ray diffraction (nano scale) in their work; others explored large animals, industrial complexes and outer

space (immense scale).

Lisa Perez Jackson has led the Apple Corporation to develop renewable energy sources for their facilities.

\subsection{Study Design and Setting}

The study took place at a one-week summer music day camp held on the campus of a university and sponsored by the music department of the university. The theme of the music camp was "Full STEAM Ahead," meaning 
STEM (Science, Technology, Engineering, and Mathematics) education with integrated arts activities (the " $A$ " in STEAM). Over a hundred students attended the K-12 camp. Each student chose an elective course for early morning that was somehow related to the camp's theme. The dioramas of women scientists' course was one of those electives and fit well with the theme because of the focus on learning about scientists through the artwork of a three-dimensional diorama.

The study had a simple pretest-posttest experimental design with all students participating in the lesson activities. Students attended an approximately 45-minute lesson each of the five days of the camp and participated in music-related activities of the day camp the rest of the week. They responded to a pretest on the first day, an attitude survey on Day 2 and Day 4, and a posttest with two additional insight questions on the last day. The outline of the daily lessons is shown in Table 2.

\subsection{Study Instrumentation}

A short pretest-posttest attitude survey of ten items to which students responded by circling "really disagree,"

\section{Table 2. Plan for teaching the dioramas of women scientists lesson unit.}

Day Activity

1 Pretest administered.

5 minutes

Who am I? Ice-breaker game. Students play game in which the name, photo, and work topic of a well-known scientist is taped to each student's back (e.g., Marie Currie, Albert Einstein). Students ask a "yes-no" answerable question to each classmate to discover the identity of the scientist.

Painting. Students receive a diorama base and paint the inside with acrylic paints.

Scientist information. Students listen to two slide show presentations about the life and work of women scientists: Mary Leakey (paleontologist and archaeologist) and Barbara McClintock (corn geneticist).

2 Icebreaker game. Students play the "Who am I?” game again with a different scientist taped to back.

20 minutes

Painting. Students paint the outside areas with acrylic paints.

15 minutes

5 minutes

20 minutes

Cutting. Students receive about 5 pages of color images for their chosen or assigned scientist and cut them out.

Scientist Information. While cutting out images, students listen to two more presentations about scientists: Ellen Ochoa (shuttle astronaut) and Patricia Bath (ophthalmologist).

Day 2 survey administered.

20 minutes

5 minutes

3 Diorama construction. Students glue the front of the face image to cardboard, cut it out again, and then glue the bottom inch of it to the upper front of the box so that the scientist's head stands upright above the box. They then glue the matching back side to the back of the face so that the bottom inch of it is glued inside the box front panel. Scientist information. Students listen to two slide show presentations of scientists: Dorothy Crowfoot Hodgkin (chemist and crystallographer) and Tolani Francisco (large animal veterinarian).

Diorama Construction. Students work to glue images to the front of the box to decorate the building and to label the box with the scientist's name. Then they begin working on the inside of the building and the opposite scene of the scientist working.

4 Scientist vocabulary game: Students play a new game in which each student is given a scientific career term such as "environmentalist" or "crystallographer" and they must find the classmate with the corresponding definition of the scientist term.

Students continue decorating the sides of their dioramas with information and images.

Students listen to the final two slide show presentations about women scientists: Joan Esnayra (Geneticist) and Lisa Perez Jackson (Environmentalist).

Each student receives an identical set of ten craft items from which to construct a scene related to his or her scientist, using all of the materials. They first generate several ideas related to the scientist, then choose one and begin to construct it. The scene is glued to the back of the box.

Day 4 survey administered.

10 minutes

15 minutes

20 minutes

5 minutes

15 minutes

20 minutes

5 minutes

5 Diorama completion. Students work to complete all parts of the diorama including the creative activity on the back panel.

Final Game: Students who have completed their dioramas play a simplified whiteboard version of Wheel of Fortune ${ }^{\circledR}$ with woman scientist-related puzzles; other students continue working on their dioramas.

20 minutes

15 minutes

Posttest with two additional questions about insights administered.

10 minutes

Diorama display. Finished dioramas are put on display for parents as they pick up students at the end of the week-long day camp. Students take their dioramas home. 
"kind of disagree," "neutral," "kind of agree,” or "really agree” was developed to measure student attitudes during the project. These items were scored from " 1 " for "really disagree" to "5" for "really agree." The first three items were taken from a large scale market research survey conducted in the United Kingdom for the Institute of Electrical Engineers (The Research Business, 1994): "Science is interesting," "Science is useful for jobs," and "Science is easy." The fourth item measured students' personal ideas about a science career: "I plan to have a career in science." The fifth item addressed attitude toward science's cultural usefulness: "The work of scientists improves our lives." The final five items were created to measure important concepts related to women in science. These items were: "It is important for women to become scientists," "Females do as well as males in science," "Females have made important science findings," "Women scientists can help others through their science careers," and "Women in science can make science more caring."

Both pretest and posttest requested the participants to list historic or living women scientists and the areas in which they worked. The posttest contained two additional open-ended questions: "What did you learn about women in science that surprised you?" and "What new ideas or feelings do you have about science now?"

\subsection{Materials and Equipment for the Dioramas of Women Scientists}

The following list of materials and equipment was used to create the dioramas: an empty cardboard food product box for each student approximately $7 \times 7 \times 1.5$ inches (about $18 \times 18 \times 4$ centimeters) in dimension or larger; a smaller empty cardboard box, approximately $4 \times 6 \times 1.5$ inches (about $10 \times 15 \times 4$ centimeters) for each student (attached to front of larger box as a building); white copy paper for covering the boxes to make the papiermâché base (recycled paper printed on one side may be used; place printed side down); scissors; white craft glue (Aleene's Original Tacky Glue is thick and effective, but any brand will work); canvas drop cloths or paper to protect table tops from glue (it is water-soluble, but takes effort to scrub off) and acrylic paint; paint brushes; white acrylic gesso (provides an excellent surface for painting and stiffens the box); acrylic paints of many colors (these non-toxic paints rub off skin, but are permanent on clothing once dry; tempera paints are not recommended-glue makes the paints wet again when the paper images are applied); paint cover-ups for students (the teachers provided large t-shirts that students wore to protect clothing); images and text explanations or labels printed in color on cardstock (the teachers made a PDF file of sized images with text and printed them on cardstock at a copy shop; soluble ink-jet images are not recommended as drops of glue make the ink run); small, cube-shaped pieces of stiff sponge-like foam packing material or Styrofoam for making the pop-out parts of a photographic scene of the scientist working; various small artifacts related to the chosen scientists' work to be attached to the box (e.g., stone tools, corn kernels, crystals, rocks, fossils, small animal figures, toy doctor tools); one identical set of ten items for each student for the creative activity glued to the back of the diorama.

\subsection{Procedures for Making the Dioramas}

The procedure for making the diorama bases is shown in Figure 1. The four teachers (a professor and three doctoral students majoring in curriculum and instruction) prepared the diorama bases, example dioramas, and pages of images before the five-day class began so that students would be able to complete the dioramas in the given time. The professor has made other diorama projects with elementary students and they were able to prepare the diorama bases. Readers should consider having upper elementary students make their own diorama bases (a one to two-hour task) if time permits.

The final creative activity involved making a scene on the back panel of the diorama related to the scientist's life or work by using all ten pieces of an identical set of given items. The items we used are shown in Figure 2. The set consisted of 1) a red speckled cardboard frozen food tray, 2) a yellow fuzzy chenille stick, 3) a white cardboard piece of packaging material, 4) a spherical gold pompon, 5) a wooden Popsicle stick, 6) a six-inch piece of pink grosgrain ribbon, 7) a $3 \times 2$ inch (about $8 \times 5$ centimeter) piece of green glitter sheet foam, 8) a small yellow envelope, 9) a strand of five plastic shamrocks molded onto a string cut from a necklace, and 10) a small plastic branch with three fabric leaves.

\section{Observations and Discussion}

\subsection{Student-Made Dioramas}

Students were thoroughly engaged in the work of making their dioramas. Figure 3 illustrates students strongly 


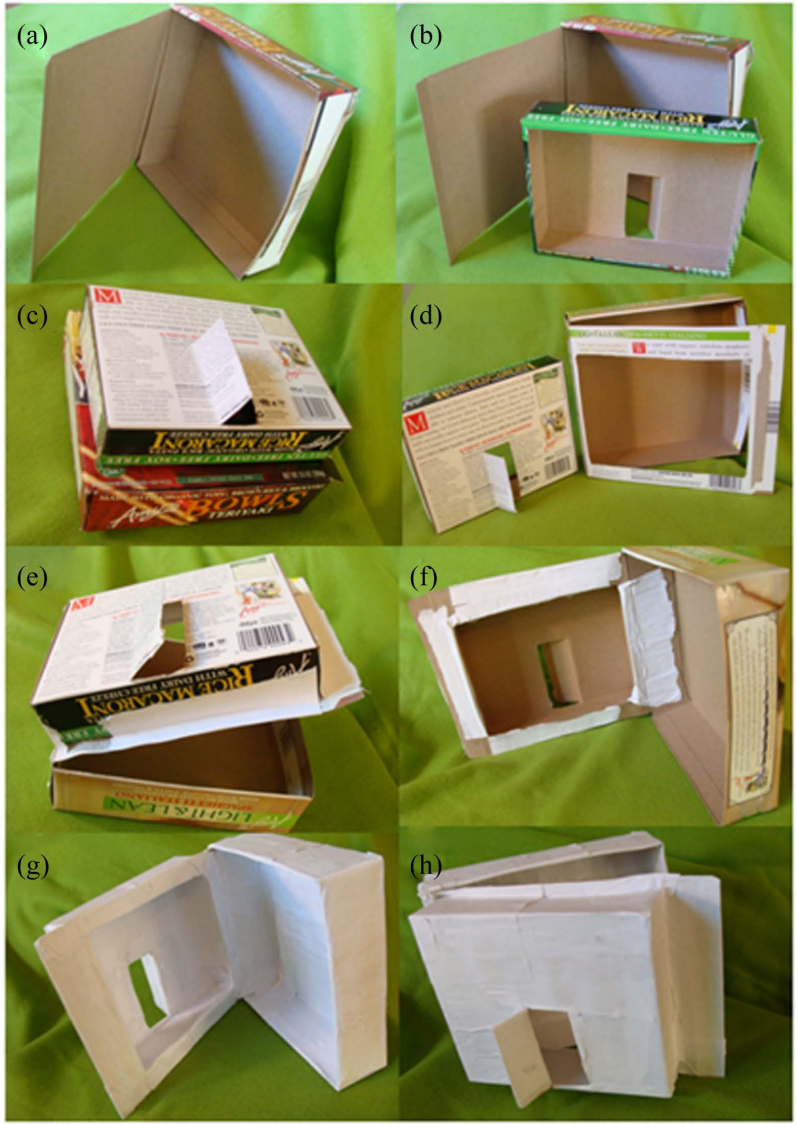

Figure 1. Steps in making a diorama base. The diorama base requires two boxes: a cardboard food product box that is approximately $7 \times 7 \times 1.5$ inches in dimensions and another smaller box approximately $5 \times 6.5 \times 1.5$. (a) Cut the large box so that it opens like a book. Add additional cardboard to the front flap edge (about 0.75 inch) so that the front flap does not fall into the box; (b) Cut the back side off of the smaller box and cut a door in the front panel; (c) Place the smaller box on top of the front of the larger box. Trace the rectangle of the smaller box onto the front panel of the larger box; (d) Cut out the rectangle; (e) Position the smaller box on the front of the larger box over the rectangular hole. Use glue-coated (on one side) torn pieces of white copy paper in a manner similar to tape to attach the smaller box to the front of the larger box. Use the glue-coated paper to "tape" all around the small box, securing it to the front of the box; (f) Use glue-coated torn paper pieces to "tape" the smaller box to the front panel from the inside. The glue-covered pieces should extend from the back of the front panel to the inside of the smaller box. Let dry a few minutes, pressing the paper so that it dries correctly; (g) Cover the entire inside of the large and small boxes with torn pieces of paper covered with glue on one side. Fold the white glue-covered pieces over the edges of the sides of the box and overlap them somewhat; (h) Cover the entire outside of the two boxes with torn, glue-coated pieces of paper. The paper should be folded over the edges of the box to form a continuous papier-mâché surface. Press on the paper and flatten or gently shape the box as it dries so that it is fairly flat with right angles. After the glue dries, coat the box on all sides with white gesso acrylic paint. This is a thick undercoat that stiffens the box and forms an effective surface for acrylic paints.

engaged in their work. Figures 4-9 present examples of the student-made dioramas. The first step during class of painting the boxes was exciting for most of the students. Many painted parts of the box different colors; some students added designs. When deciding where to place the images and information, some students relied heavily on the teacher's example diorama, but others wanted to make their dioramas unique. All students had to make adjustments because of the varying dimensions of the individual boxes. This proved beneficial because it forced students to be creative in their placement of images and text. Figures 4-6 refer to dioramas of the same four women scientists, while Figures 7-9 pertain to a second group of four women scientists. Figure 4 and Figure 7 


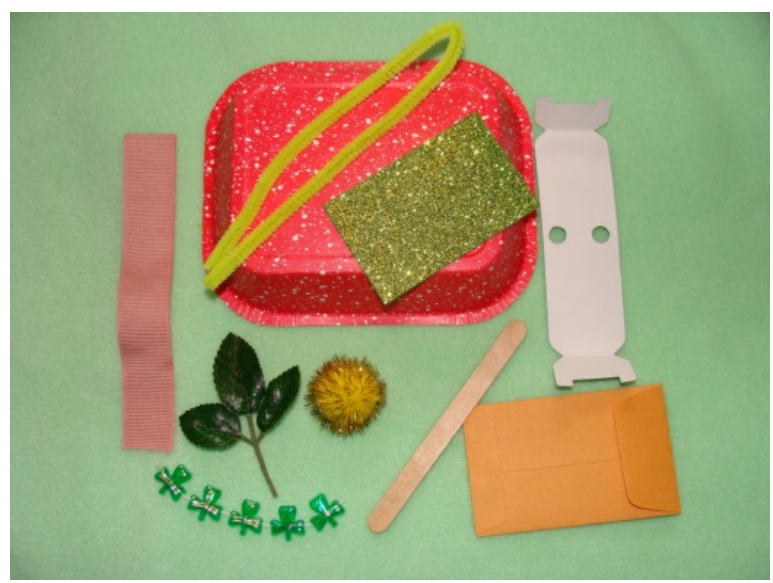

Figure 2. Ten given items used for the creative activity.

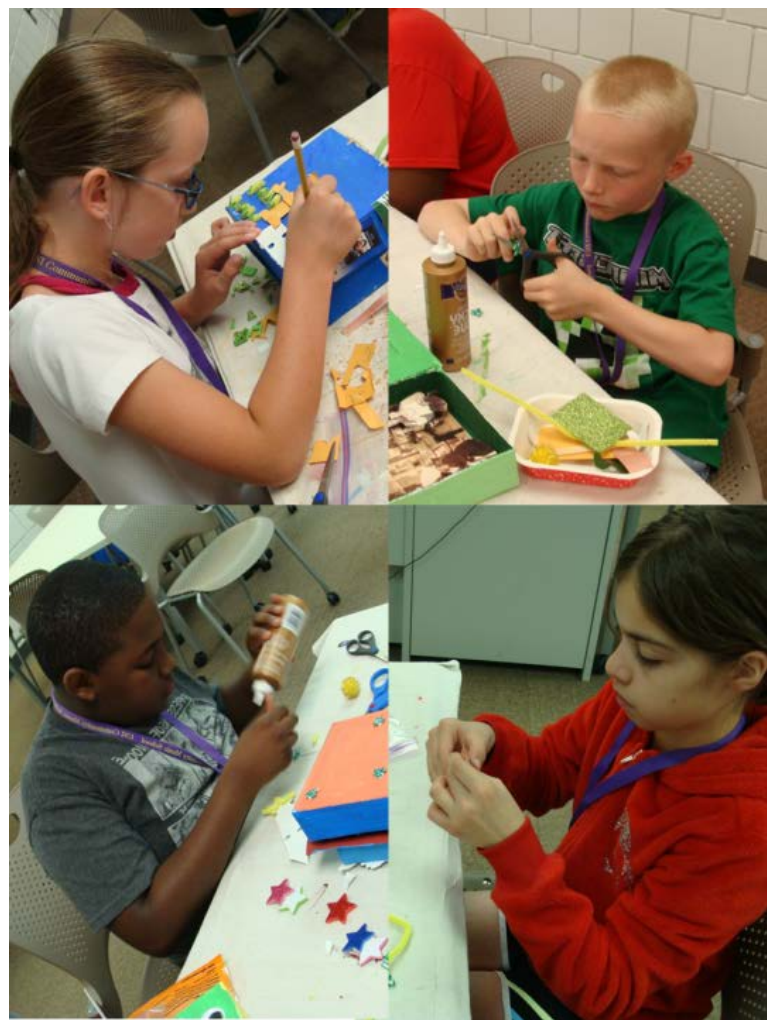

Figure 3. Girls and boys focused intently on diorama work.

show the fronts of dioramas; Figure 5 and Figure 8 display the interiors of the buildings on the front, and Figure 6 and Figure 9 show the three-dimensional pop-out scenes of the woman scientist working. After gluing images and information on the box front and narrow sides, students began the three-dimensional scenes of the box interiors. Students expressed enjoyment as they created this spatial effect within their dioramas. Many worked tirelessly to place each piece precisely, giving the best effect. This work was intense for many students, and some had difficulty leaving the project at the end of the class period. When students returned the next day, they immediately started work on the projects, showing their investment in the project.

\subsection{Pretest-Posttest Results Concerning Attitude Statements}

Cronbach's alpha, a coefficient of internal consistency of items on a test or survey, was used to estimate the 

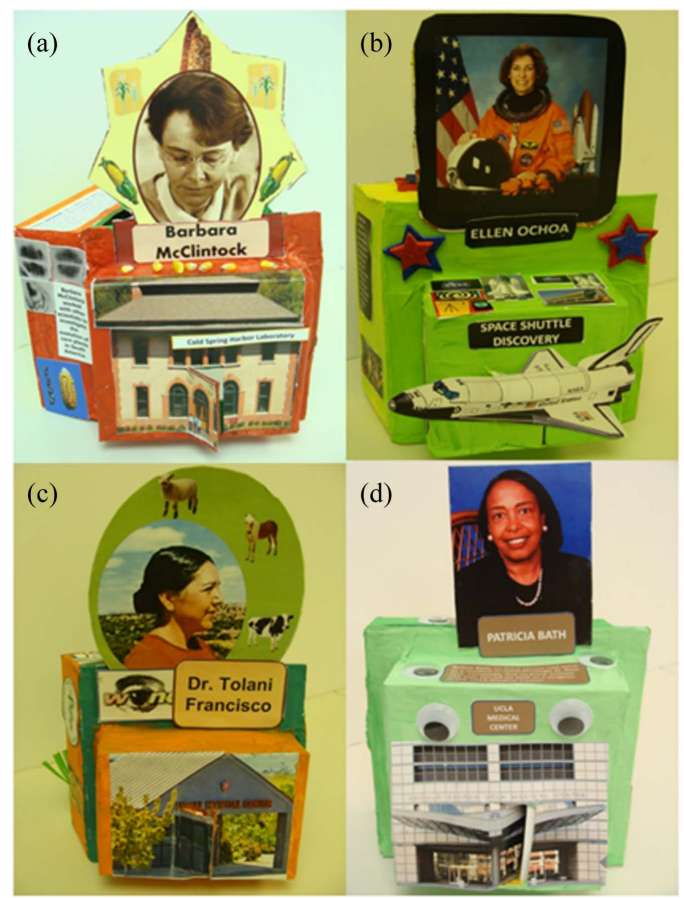

Figure 4. The fronts of the first set of student-made dioramas. (a) shows corn geneticist Barbara McClintock and the Cold Spring Harbor Laboratory at which she did much of her work; (b) features astronaut Ellen Ochoa with the space shuttle Discovery; (c) pictures large animal veterinarian Tolani Francisco with an animal hospital center; (d) shows ophthalmologist Patricia Bath and the UCLA Medical Center at which she worked.

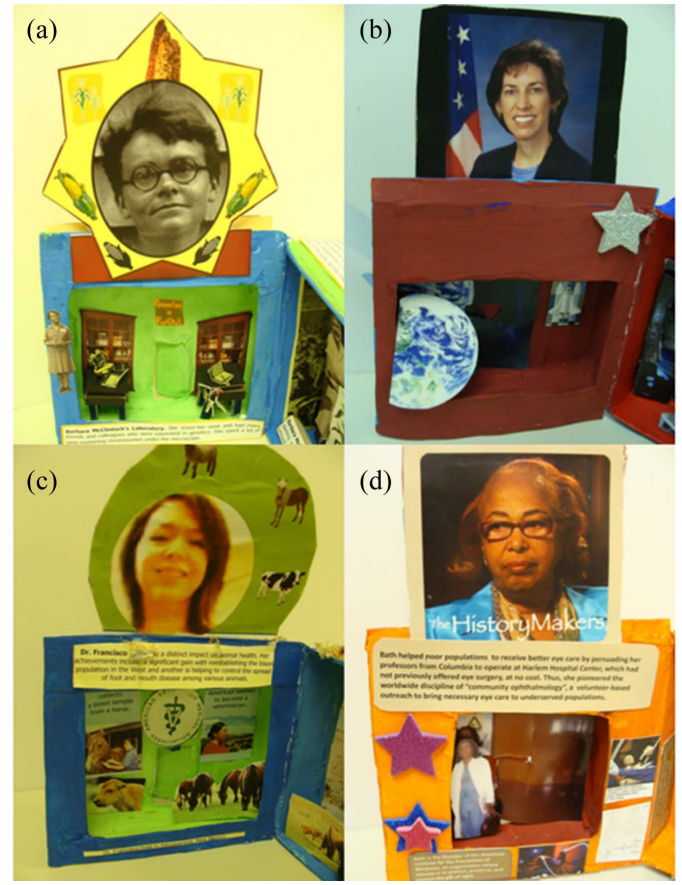

Figure 5. Interiors of the structures depicted on the cover of the dioramas of set 1 . (a) shows the interior of Barbara McClintock's laboratory with black lab tables, a microscope, notebooks, and keys; (b) shows the shuttle in space (with Ellen Ochoa aboard), traveling around earth; (c) illustrates the animals being served by Tolani Francisco; (d) depicts Patricia Bath in her white lab coat at the medical center. 


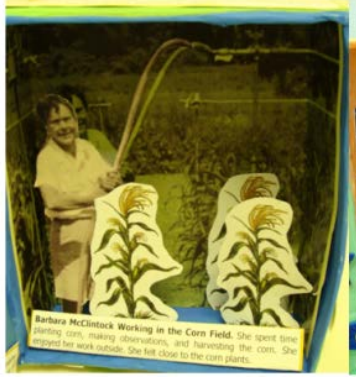

(a)

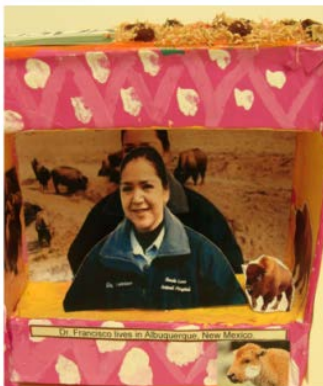

(c)

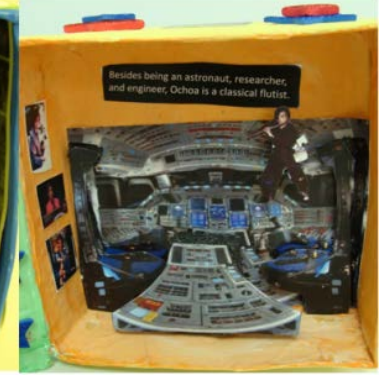

(b)

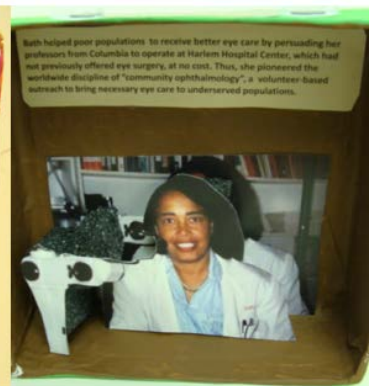

(d)

Figure 6. Three-dimensional pop-out scenes showing the scientists of set 1 at work. (a) illustrates Barbara McClintock watering plants in an experimental corn field; (b) shows Ellen Ochoa playing her flute inside the space shuttle; (c) shows Tolani Francisco thinking about the bison's disease; (d) depicts Patricia Bath with ophthalmology equipment.
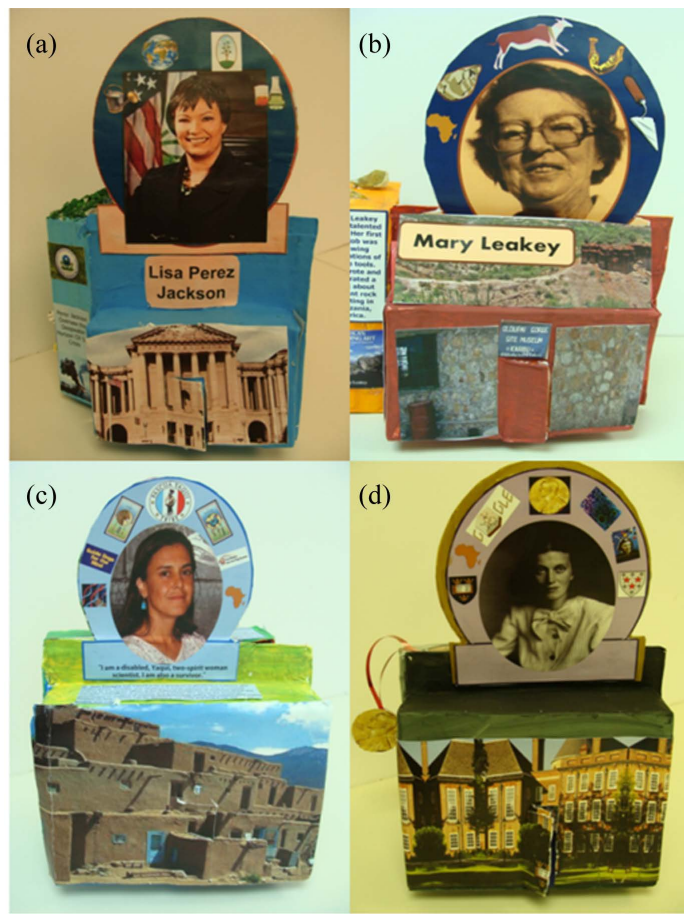

Figure 7. The fronts of the second set of student-made dioramas. (a) shows environmentalist Lisa Perez Jackson and the headquarters of the Environmental Protection Agency in Washington DC; (b) shows the Olduvai Gorge Site Museum in Tanzania that Mary Leakey initiated; (c) is Yaqui tribe Member Joan Esnayra with adobe housing. (d) features Dorothy Crowfoot Hodgkin and multifaceted view of a building from Oxford University. 


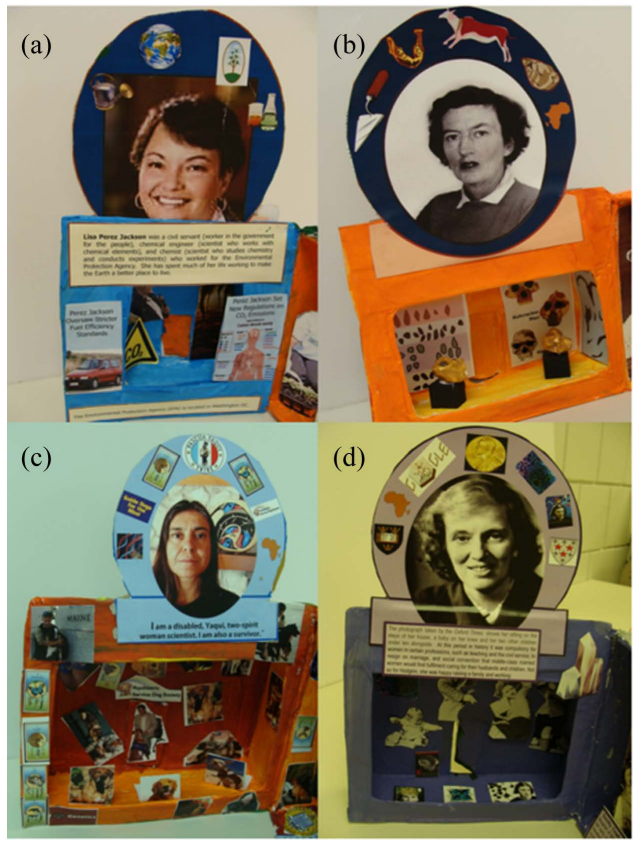

Figure 8. Interiors of the structures depicted on the cover of the dioramas of set 2. (a) shows some of the accomplishments of Lisa Perez Jackson while she was the director of the Environmental Protection Agency; (b) shows part of the interior of the Olduvai Gorge Museum containing archaeological and paleontological items from the dig. Two large Australopithecine skulls are mounted on black pedestals; (c) shows the kinds of service animals that are a part of the Psychological Service Dog Society which Joan Esnayra founded; (d) shows Dorothy Hodgkin and her children as well as two of the stamps issued in her honor.

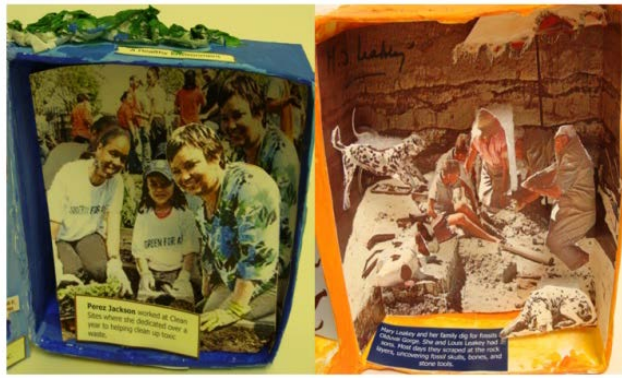

(a)

(b)

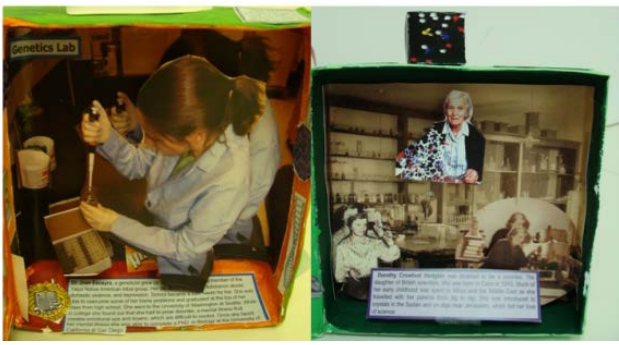

(c)

(d)

Figure 9. Three-dimensional pop-out scenes showing the scientists of set 2 at work. (a) illustrates Lisa Perez Jackson working with local volunteers to plant tomatoes at the Riverside Valley Community Garden located in Riverside Park, Harlem, New York; (b) shows the Leakey family at work scraping the rock layers in Olduvai Gorge to uncover fossils, skulls, and stone tools; (c) shows Joan Esnayra engaged in genetics work in her laboratory; (d) pictures Dorothy Crowfoot Hodgkin working in her X-ray crystallography lab at several stages of her life. 
reliability of the attitude survey, which contained ten questions. Cronbach's alpha (which varies from zero to one) was 0.81 for the women scientist attitude survey used in this study. In interpreting this result, one should consider that, in general, the higher the number, the greater the internal consistency: a Cronbach alpha score greater than 0.70 is good and above 0.90 is excellent; therefore the Cronbach alpha score for the survey was certainly in the acceptable range (Cronbach, 1970). Table 3 shows that students tended to agree (ratings of 3.5 to 4.5) or strongly agree (ratings $>4.5$ ) with most of the statements on the pretest. The two exceptions were "I plan to have a career in science" and "It is important for women to become scientists," both of which fell into the neutral rating zone $(2.5$ - 3.5). Student attitudes toward these two statements in particular evidenced large positive effect sizes as a result of the class. Exploring the interesting personal stories of diverse women scientists through viewing electronic slide presentations and making dioramas seems to have positively influenced student attitudes.

On the posttest, students expressed greater agreement (mean scores $>3.5$ ) with all of the statements except "Science is easy" and "Females do as well as males in science." The lessening of agreement with these statements may be because the struggles that many women scientists underwent to be successful were discussed in the class. For example, Mary Leakey lived in a tent in the African wilderness, spending day after day scraping the rock layers to uncover fossils, work that required a lot of self-motivation and patience. Barbara McClintock's theory of gene transposition was not accepted as applying to other organisms for many years, resulting in scientists ignoring or belittling her work. Additionally, she feared that she would not be promoted at the University of Missouri because she was female and had to find another research position. Joan Esnayra experienced a childhood of substance, physical, and sexual abuse. She struggled with mental illness stemming from these circumstances but was able to innovatively help others through service animals because she understood their positive psychological effects. She eventually realized her dream of being a scientist, working for the National Academies of Science. Patricia Bath had to overcome prejudices against women and African Americans as she advanced in her ophthalmology career, becoming an advocate for medically underserved populations. These stories of the hardships of women scientists made them more aware of the challenges women scientists may face.

Another aspect emphasized by the teachers of this class was the caring attitude of many women scientists. Previous research by Pauline Lightbody has shown that female students may not picture themselves as scientists because they don't perceive science as a feminine career focused on helping others (Lightbody \& Durndell, 1996; Lightbody et al., 1996). Additionally, research by Munro and Elsom (2000) indicated that both male and female students perceive science as preparing only useful specialists that provide no useful cultural knowledge. Therefore, we decided to emphasize the caring aspects of the female scientists we highlighted and the societal impacts of their work. For example, the teachers presented information about how Lisa Perez Jackson enacted clean air and water laws to improve the environment of others and how Patricia Bath helped many people blinded

Table 3. Mean pretest-posttest attitude scores.

\begin{tabular}{|c|c|c|c|c|c|}
\hline Statement & $\begin{array}{l}\text { Mean pretest } \\
\text { score }\end{array}$ & $\begin{array}{l}\text { Mean posttest } \\
\text { score }\end{array}$ & $\begin{array}{c}\text { Paired } t \text {-test } \\
p \text {-value }\end{array}$ & $\begin{array}{l}\text { Cohen's } d \\
\text { effect size }\end{array}$ & $\begin{array}{c}\text { Effect size } \\
\text { interpretation }\end{array}$ \\
\hline Science is interesting. & $4.20(0.9)$ & $4.40(0.8)$ & 0.19 & - & - \\
\hline Science is useful for jobs. & $4.50(0.9)$ & $4.53(0.7)$ & 0.08 & - & - \\
\hline Science is easy. & $3.47(1.1)$ & $3.20(1.1)$ & 0.22 & - & - \\
\hline I plan to have a career in science. & $2.40(1.3)$ & $3.33(1.0)$ & 0.005 & 0.80 & Large \\
\hline It is important for women to become scientists. & $3.20(1.2)$ & $4.13(1.1)$ & 0.003 & 0.81 & Large \\
\hline Females do as well as males in science. & $4.47(1.0)$ & $4.33(1.4)$ & 0.08 & - & - \\
\hline Females have made important science findings. & $4.07(1.0)$ & $4.40(1.1)$ & 0.09 & - & - \\
\hline Women can help others through their science careers. & $4.36(1.2)$ & $4.40(0.8)$ & 0.50 & - & - \\
\hline The work of scientists improves our lives. & $4.07(0.8)$ & 4.07 (1.2) & 0.50 & - & - \\
\hline Women in science can make science more caring. & $3.36(1.0)$ & $3.80(0.9)$ & 0.014 & 0.56 & Medium \\
\hline
\end{tabular}

Note: Scoring of ratings: 1 = really disagree, 2 = kind of disagree, $3=$ neutral, $4=$ kind of agree, and $5=$ really agree. Standard deviations are shown in parentheses. Effect sizes were calculated for $p$-values less than 0.05 . 
by cataracts to regain their vision. Women scientists' caring for animals was also highlighted. Examples included the concern that veterinarian Tolani Francisco had for her large animal patients, the affection Mary Leakey had for the charming African hyraxes that stole food from the dinner table, and Joan Esnayra's desire to help others with psychological problems through service animals. This approach resulted in a medium effect size change in student attitudes from pretest to posttest on the statement, "Women in science can make science more caring."

An open-ended question on the pretest and posttest asked students to name well-known women scientists. On the pretest no students were able to name a woman scientist and her area of work. On the posttest, students were able to recall an average of three names of women scientists and their correct corresponding areas of work.

\subsection{Attitude Surveys from Day 2 and Day 4}

Before the class started, the professor sent an email message to all participants explaining that assessment data would be collected to evaluate the efficacy of the project (participants had been made aware of the data collection when they registered for the course), providing short descriptions of the eight women scientists on which the class focused, and asking for each students' top three choices of the eight scientists. This allowed the teachers to assign scientists for the student dioramas so that all eight were addressed in the class. Although a title and short description of the class had been available at registration, a few parents had not realized that the course focused on female scientists and they replied that their sons were concerned about whether there would be other boys in the class and whether they might choose a male scientist. The professor responded that half of the class was male, but that the topic would remain female scientists, as it was important for everyone to become aware of the often-overlooked contributions of women to science. Some male students were somewhat apprehensive at the start of class, but after the game that focused on scientists of both sexes and the exciting opportunity to paint the three-dimensional diorama with acrylic paints, everyone settled in quite happily. No complaints were made about the female scientist focus during the week. In fact, as the week progressed, the interest and pride of the boys in the women scientists on which they were concentrating was apparent as they often bragged to classmates about the accomplishments of their particular scientist while working on the diorama. Table 4 presents student ratings of creativity, enjoyment, and learning on the second and fourth days of class. Students were also asked to give two reasons for each of their ratings.

Student creativity and enjoyment of the course increased as students became more involved. Students felt most creative during the special activity designed to require creative thinking, the activity in which students made a scene using ten given craft items. However, there were other opportunities for students to work creatively. Each diorama base was somewhat different in size, as many different small boxes had been used to make the building on the front. Students, therefore, had to determine ways to fit the color images to the size and shape of box each had chosen. Arranging items on the panels of the box and in scenes was done individually, leaving room for creative expression.

The teachers observed that students were very engaged in the diorama work, especially the creative assignment of making something related to the scientist on the back of the box with the ten given materials. Twelve students stated that they used their imaginations to think of creative ways for using the given ten items as a reason for rating this activity high in creativity. Students expressed that they felt challenged, but were having a lot of fun completing the activity. This fits with the state of flow in which a person is challenged to use many available skills, resulting in a sense of timelessness, continuous flow of ideas, and deep satisfaction (Csikszentmihalyi, 1990). In fact, many students remarked that time passed very quickly when they were working on the dioramas.

Table 4. Student mean ratings of creativity, enjoyment, and learning on a scale of " 1 " to " 10 " with " 1 ” being "low" and " 10 " being "high".

\begin{tabular}{cccc}
\hline Day & Mean rating for creativity & Mean rating for enjoyment & Mean rating for learning \\
Day 2 & $6.9(2.5)$ & $7.9(2.4)$ & $6.6(2.8)$ \\
Day 4 & $9.1(1.7)$ & $8.4(1.6)$ & $6.8(2.7)$ \\
\hline
\end{tabular}

Note: Standard deviations are shown in parentheses. 
In general, students found the diorama project very enjoyable. Students justified high enjoyment ratings by citing the fun of making a three-dimensional diorama and the challenge of using their imaginations to produce the creative scene on the back side. Students also referred to enjoyment of paint color mixing, paper image cutting, and glue work as highly enjoyable, particularly because they had few other opportunities for these types of activities. Teachers observed that students arrived each day ready to work on their dioramas. Sometimes it was difficult to get students to stop working and prepare to go to their next class. Students enjoyed the hands-on construction activities and expressed that they seldom have such opportunities at school. Many schools have eliminated arts-integrated model-making projects, replacing them with computer technology labs, or with more reading and mathematics lessons to prepare for high-stakes testing (Au, 2007; Spohn, 2008). However, a recent study found that students displayed more science content information through hands-on arts-integrated projects as compared to technology projects (Klopp et al., 2014).

Regarding science learning, students noted specific information about women scientists that they had retained. Ten students mentioned how the scientists had helped other people. One student remarked, "These people are really caring; I wish I could have known them.” Five girls remarked that they were pleased to learn that female scientists are as capable as male scientists. A student working on a diorama of Ellen Ochoa was placing colorful red, white and silver stars on her diorama. She said, "All the scientists deserve stars because they are heroes in my eyes." A male student who was working on a diorama of a Nobel prize-winning scientist, asked the teacher for foam to separate the two sides of the medal he was gluing together so that the medal would look three-dimensional. He explained that the medal was an honor and he wanted it to be special for his scientist because she deserved it.

\subsection{The Creative Activity}

Figure 10 and Figure 11 present some of the creative scenes made by students using the given set of ten craft items. After receiving the bag of items, students generated several possible themes for their scenes. Some students planned the scene carefully, while others took items one at a time and started construction. Most students had a couple of craft items that required more problem-solving to fit into the scene. However, almost everyone was able to incorporate at least parts of all ten items. Using all the provided items exercises the creative skill of fluency (generating many ideas). Another creative thinking skill is flexibility. This skill is evidenced when a student repurposes a material. For example, using the leaf as a tissue to wipe tears (Figure 10(d)) or part of a crystal pattern (Figure 11(d)), rather than as part of a plant, showed flexibility. Elaboration, attention to detail, was shown by the student who made the veterinary scene in Figure 10(c). He added decoration to the white fence, drew butterflies, sketched flower centers, and fringed the glitter foam to make tall grass. Some students made their scenes three-dimensional, another creative trait. The student in Figure 10 made a protruding red cover for a document; the student in Figure 10(d) had a pop-out ophthalmology machine; and the maker of Figure 11(c) showed a hair strand extending from the microscopic view. Many students used their imaginations to develop fantasy stories about their scenes. For example, the maker of the scene in Figure 10(d) imagined Ellen Ochoa traveling out of the regular shuttle orbit to "reach for the stars" by heading for the nearest star, the sun and the student creator of Figure 11(b) developed a story about his cave painting of a well-loved medicine man.

\subsection{Additional Posttest Questions Involving Insight}

At the end of the week, students responded to two additional questions on the posttest that called for their insights about the course. The first question was "What did you learn about women in science that surprised you?" Both female and male students provided the most frequent observation that women can be equal to men in science and help the world. The message that the investigators sent about women scientists being caring seemed to have been received. Several students named a specific accomplishment of a woman scientist that was studied such as Ellen Ochoa was Director of NASA, Barbara McClintock discovered jumping genes, Patricia Bath helped the blind, and Tolani Francisco worked on large wild animals. Students noted that many women scientists struggled against prejudice and unfair treatment, but diversity discrimination did not stop them. Another interesting response from one student was "they discovered things that I thought men discovered." This comment shows the previous mindset of the student that women had contributed little to science.

Responses to another question, "What new ideas or feelings about science do you now have?" revealed that many students now observed science as fun and exciting or that they had not enjoyed science previously, but 


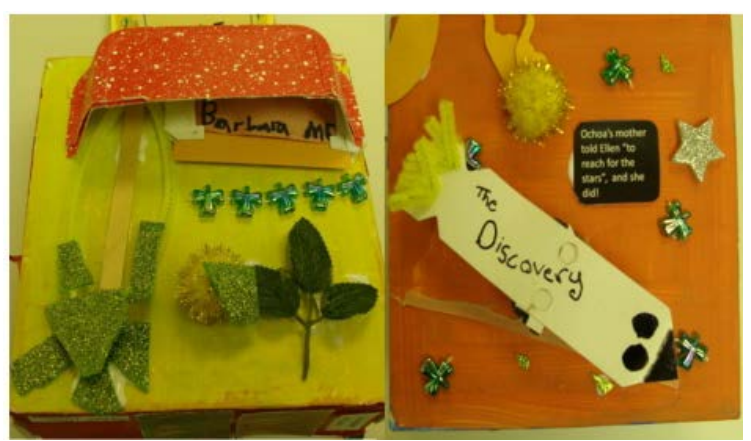

(a)

(b)

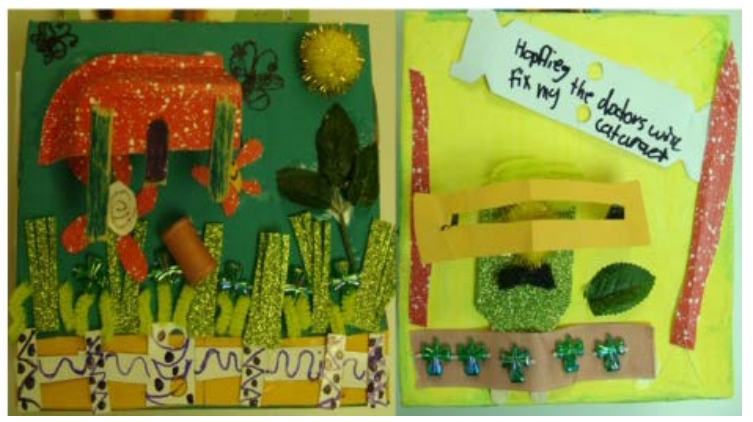

(c)

(d)

Figure 10. Example creative activity scenes glued to the backs of the first set of dioramas. (a) depicts a scene of the evolution of corn related to Barbara McClintock. Corn started out as a leafy plant with a small seed (on the far right near the bottom). Then, it has a tiny cob symbolized by the gold pompon in the middle. Finally, it has a large cob as shown at left with the chenille stick outlining the cob. The red tray is a cover that hides McClintock's secret genetic research on corn. The green shamrocks represent other green plants at the back of the corn field; (b) shows the Discovery Space Shuttle piloted by Ellen Ochoa as it soars with the sun and stars in the background; (c) depicts a scene related to large animal veterinarian Tolani Francisco. The white fencing at the bottom represents a corral for the animals. The rolled grosgrain ribbon represents a hay bale containing medicine for the animals. The butterflies have eye designs on their wings to scare away predators; (d) shows a man with a moustache who has cataracts receiving an eye examination from Patricia Bath (not shown).

now like it. Five students responded that scientists can help the world, again indicating that they now perceived successful women scientists as compassionate. These effects were highly desirable as student excitement about and positive regard for science are needed to encourage choice of careers in STEM fields. Four students also responded that they now believe that anyone, male or female, can become a scientist, in contrast to their earlier belief that all scientists are male. One 5-hour project is not likely to convert female students to planning a career in science, but it can be an effective link in the chain of events that leads in that direction.

\section{Conclusion}

Technology and standardized tests are an important reality in schools today, but educators must not forget that actively engaging students in hands-on creative activities is still a powerful learning tool necessary for wellrounded students. The imaginings our students participated in as they built the scenes of their dioramas are part of fantasy play, crucial for social, emotional, and cognitive development (Moyer, 2014). Imagining oneself in various careers, including its everyday work patterns, helps to prepare students for them and facilitates students being more patient and persistent (Bergen \& Fromberg, 2009; Singer \& Singer, 2006).

Students found the diorama project highly engaging, increasing their knowledge of and appreciation for the contributions of women scientists. Students were also reported to have an increased desire for science careers. Therefore, the authors strongly recommend that teachers consider implementing this project with upper elementary students. Although the preparation for the project required several hours of researching the scientists, 


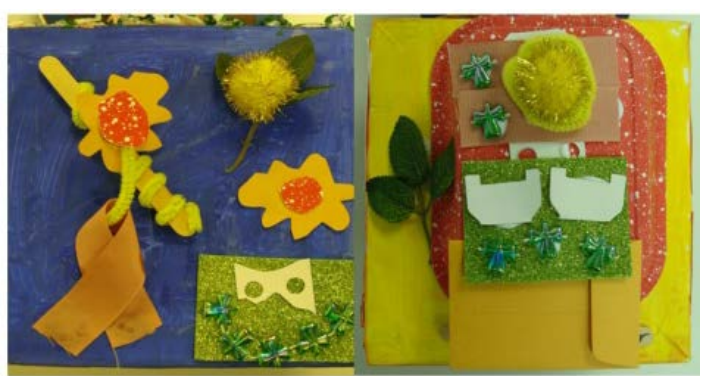

(a)

(b)

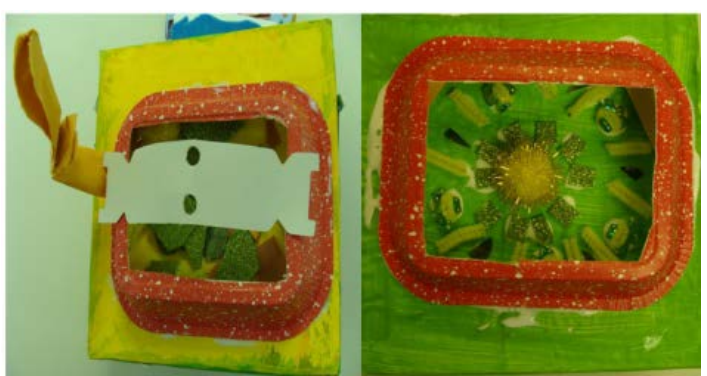

(c)

(d)

\begin{abstract}
Figure 11. Second set of example creative activity scenes glued to the backs of the dioramas. (a) depicts objects related to Lisa Perez Jackson. At the left is a ribbon and flower symbolizing plantings that enrich the earth. At the bottom right is the green earth smiling because she is receiving care. The Popsicle stick has a vine entwining it to show the strength of nature; (b) is related to the work Mary Leakey did in publishing a book about cave paintings. This is a cave painting of the skull of a deceased tribal leader and medicine man. The yellow pompon represents a doctor's light on the forehead. The two eye sockets are the holes punched in white cardboard that is almost covered by a face mask of green glitter foam and yellow envelope paper. The green shamrocks are badges that show honors earned as a leader; (c) is a view of DNA through the microscope related to Joan Esnayra's work. The protruding yellow construction on the left is a magnified hair; (d) depicts a crystal diffraction pattern similar to those used by Dorothy Crowfoot Hodgkin.
\end{abstract}

preparing electronic slide shows about them, and creation of example dioramas, with more time allotted to the work for students, much of this effort could be shifted to them with increased student benefits. The next section explains how this might be done.

\title{
5. Extensions and Cross-Curricular Applications
}

The researchers were heavily constrained by the one-week day camp model in which teachers had about 45 minutes a day for five days with the students. The investigators would have liked to have had additional time so that students could examine and learn about the women scientists the teachers had chosen, but then select and investigate a new female scientist on their own or in pairs, making a unique diorama on that person. However, the investigators had spent several hours researching scientists and locating appropriate images, so they knew that the day camp students would not have time to investigate a new scientist.

The reader may want to extend the diorama project presented here to allow students to connect reading and writing skills to their investigations of women scientists. Common Core standards (Common Core State Standards Initiative, 2012) for fourth grade literacy addressed by student research are shown in Table 5. A checklist of what to ask students to find about the scientist would facilitate this work. Ideas for the checklist include: 1) Images: Find photographs of the scientist's face, of her working, of a building associated with her (perhaps a laboratory, office building, museum, university, home) and of the interior of the building (for the interior diorama scene); 2) Science work: Find out what science topics and concepts she worked on, what her contributions to science and society were, any awards she received, and objects associated with her work (for inclusion in the diorama scenes); 3) Personal: locate information about her personality, the challenges she faced, her education path to her science career, what she cared about most, and any interesting quotes from her. 
Table 5. Common core literacy standards applied to independent student research into a woman scientist for creating a unique diorama.

\begin{tabular}{ll}
\hline Common core standards for literacy & Application of standard to diorama project \\
$\begin{array}{l}\text { RI.4.1 Refer to details and examples in a text when explaining } \\
\text { what the text says explicitly and when drawing inferences from } \\
\text { the text. }\end{array}$ & $\begin{array}{l}\text { Explain where details portrayed or written on the diorama originated } \\
\text { in text. }\end{array}$ \\
$\begin{array}{l}\text { RI.4.3 Explain events, procedures, ideas, or concepts in a } \\
\text { historical, scientific, or technical text, including what happened } \\
\text { and why, based on specific information in the text. }\end{array}$ & $\begin{array}{l}\text { Explain details of women scientists' lives and illustrate these as three } \\
\text { dimensional diorama scenes. }\end{array}$ \\
$\begin{array}{l}\text { RI.4.9 Integrate information from two texts on the same topic in in } \\
\text { order to write or speak about the subject knowledgeably. }\end{array}$ & $\begin{array}{l}\text { Use book, journal article, and Internet sources to discover information } \\
\text { about a scientist, integrating the ideas from multiple sources. }\end{array}$ \\
$\begin{array}{l}\text { W.4.2 Write informative/explanatory texts to examine a topic } \\
\text { and convey ideas and information clearly. }\end{array}$ & $\begin{array}{l}\text { Write a short summary of the work of the scientist to be glued to the } \\
\text { diorama. Create informative labels for diorama objects and scenes. }\end{array}$ \\
$\begin{array}{l}\text { W.4.7 Conduct short research projects that build knowledge } \\
\text { through investigation of different aspects of a topic. }\end{array}$ & $\begin{array}{l}\text { Investigate various websites and print sources for information about the } \\
\text { life, work, and personal history of the scientist, taking notes that will } \\
\text { inform the diorama. }\end{array}$ \\
\hline
\end{tabular}

\section{Acknowledgements}

This research project was funded in part by the Center for Educational Transformation at the University of Northern Iowa in Cedar Falls, Iowa. The authors also thank Cynthia Mason and Michelle Swanson of the University of Northern Iowa School of Music for assistance during this project, which was part of Camp Musicmania.

\section{References}

Achieve Inc. (2013). Next Generation Science Standards. Washington DC: Achieve Inc.

American Association for the Advancement of Science (1993). Benchmarks for Science Literacy. New York: Oxford University Press.

Archer, L., DeWitt, J. Osborne, J., Dillon, J., Willis, B., \& Wong, B. (2012). "Balancing Acts”: Elementary School Girls' Negotiations of Femininity, Achievement, and Science. Science Education, 96, 967-989.

http://dx.doi.org/10.1002/sce.21031

Au, W. (2007). High-Stakes Testing and Curricular Control: A Qualitative Metasynthesis. Educational Researcher, 36, 258267. http://dx.doi.org/10.3102/0013189X07306523

Bergen, D., \& Pronin Fromberg, D. (2009). Play and Social Interaction in Middle Childhood. Phi Delta Kappan, 90, 426-430. http://dx.doi.org/10.1177/003172170909000610

Bettinger, E. P., \& Long, B. T. (2005). Do Faculty Serve as Role Models? The Impact of Instructor Gender on Female Students. American Economic Review, 92, 152-157. http://dx.doi.org/10.1257/000282805774670149

Chemers, M. M., Zurbriggen, E. L., Syed, M., Goza, B. K., \& Bearman, S. (2011). The Role of Efficacy and Identity in Science Career Commitment among Underrepresented Minority Students. Journal of Social Issues, 67, 469-491.

http://dx.doi.org/10.1111/j.1540-4560.2011.01710.x

Common Core State Standards Initiative (2012). Implementing the Common Core State Standards. http://www.corestandards.org/

Correll, S. J. (2004). Constraints into Preferences: Gender, Status, and Emerging Career Aspirations. American Sociological Review, 69, 93-113. http://dx.doi.org/10.1177/000312240406900106

Cronbach, L. J. (1970). Essentials of Psychological Testing. New York: Harper \& Row.

Csikszentmihalyi, M. (1990). Flow: The Psychology of Optimal Experience. New York: Harper Perennial.

Di Fabio, N. M., Brandi, C., \& Frehill, L. M. (2008). Professional Women and Minorities: A Total Human Resources Data Compendium. Washington DC: Commission on Professionals in Science and Technology.

Downs, R., \& De Souza, A. (2006). Learning to Think Spatially: GIS as a Support System in the K-12 Curriculum. Washington DC: Committee on the Support for the Thinking Spatially, National Research Council. The National Academies Press.

Dweck, C. (2006). Is Math a Gift? Beliefs That Put Females at Risk. In S. J. Ceci, \& W. M. Williams (Eds.), Why Aren't More Women in Science? Top Researchers Debate the Evidence (pp. 47-55). Washington DC: American Psychological Association. 
Dweck, C. (2008). Mindsets and Math/Science Achievement. New York: Carnegie Corporation of New York, Institute for Advanced Study, Commission on Mathematics and Science Education.

Fouad, N. A., Hackett, G., Smith, P. L., Kantamneni, N., Fitzpatrick, M., Haag, S., \& Spencer, D. (2010). Barriers and Supports for Continuing in Mathematics and Science: Gender and Educational Level Differences. Journal of Vocational Behavior, 77, 361-373. http://dx.doi.org/10.1016/j.jvb.2010.06.004

Heilman, M. E., Wallen, A. S., Fuchs, D., \& Tamkins, M. M. (2004). Penalties for Success: Reactions to Women Who Succeed at Male Gender-Typed Tasks. Journal of Applied Psychology, 89, 416-427. http://dx.doi.org/10.1037/0021-9010.89.3.416

Heilman, M. E., \& Okimoto, T. G. (2007). Why Are Women Penalized for Success at Male Tasks? The Implied Communality Deficit. Journal of Applied Psychology, 92, 81-92. http://dx.doi.org/10.1037/0021-9010.92.1.81

Hewlett, S. A., Luce, C. B., Servon, L. J., Sherbin, L., Shiller, P., Sosnovich, E., \& Sumberg, K. (2008). The Athena Factor: Reversing the Brain Drain in Science, Engineering and Technology. Watertown, MA: Harvard Business School.

Hill, C., Corbett, C., \& St Rose, A. (2010). Why So Few? Women in Science, Technology, Engineering, and Mathematics. Washington DC: American Association of University Women.

Iowa Department of Education (2013). Iowa Core 21st Century Skills. www.educateiowa.gov/documents/iowa-core/2013/04/iowa-core-21st-century-skills-doc

Johnson, K. V., \& Watson, E. D. (2005). A Historical Chronology of the Plight of African Americans Gaining Recognition in Engineering and Technology. Journal of Technology Studies, 31, 81-93.

Klopp, T. J., Rule, A. C., Schneider, J. S., \& Boody, R. M. (2014). Computer Technology-Integrated Projects Should Not Supplant Craft Projects in Science Education. International Journal of Science Education, 36, 865-886. http://dx.doi.org/10.1080/09500693.2013.829927

Leaper, C. L., \& Brown, C. S. (2008). Perceived Experiences with Sexism among Adolescent Girls. Child Development, 79, 685-704. http://dx.doi.org/10.1111/j.1467-8624.2008.01151.x

Lightbody, P., \& Durndell, A. (1996). The Masculine Image of Careers in Science and Technology—Fact or Fantasy. British Journal of Educational Psychology, 66, 231-246. http://dx.doi.org/10.1111/j.2044-8279.1996.tb01192.x

Lightbody, P., Siann, G. Stocks, R., \& Walsh, D. (1996). Motivation and Attribution at Secondary School: The Role of Gender. Educational Studies, 22, 13-25. http://dx.doi.org/10.1080/0305569960220102

Mead, M., \& Métraux, R. (1957). Image of the Scientist among High-School Students. Science, 126, 384-390. http://dx.doi.org/10.1126/science.126.3270.384

Miller, P. H., Blessing, J. S., \& Schwartz, S. (2006). Gender Differences in High-School Students’ Views about Science. International Journal of Science Education, 28, 363-381. http://dx.doi.org/10.1080/09500690500277664

Moyer, M. W. (2014). The Serious Need for Play: Free, Imaginative Play Is Crucial for Normal Social, Emotional, and Cognitive Development. It Makes Us Better Adjusted, Smarter, and Less Stressed. Scientific American Mind, 23, 78-85. http://dx.doi.org/10.1038/scientificamericancreativity1213-78

Munro, M., \& Elsom, D. (2000). Choosing Science at 16: The Influences of Science Teachers and Careers Advisors on Students' Decisions about Science Subjects and Science and Technology Careers. Cambridge: National Institute for Careers Education and Counseling.

National Science Foundation (2008). Science and Engineering Degrees: 1966-2006. Arlington, VA: Division of Science Resources Statistics.

National Science Foundation (2009). Women, Minorities, and Persons with Disabilities in Science and Engineering. Arlington, VA: Division of Science Resources Statistics. www.nsf.gov/statistics/wmpd

Nosek, B. A., Banaji, M., \& Greenwald, A. G. (2002). Harvesting Implicit Group Attitudes and Beliefs from a Demonstration Web Site. Group Dynamics: Theory, Research, and Practice, 6, 101-115.

Perna, L., Lundy-Wagner, V., Drezner, N. D., Gasman, M., Yoon, S., Bose, E., \& Gary, S. (2009). The Contribution of HBCUs to the Preparation of African American Women for STEM Careers: A Case Study. Research in Higher Education, 50, 1-23. http://dx.doi.org/10.1007/s11162-008-9110-y

The Research Business (1994). Views of Science among Students, Teachers and Parents. Institution of Electrical Engineers.

Root-Bernstein, R. S., \& Root-Bernstein, M. M. (2013). The Art and Craft of Science: Scientific Discovery and Innovation Can Depend on Engaging More Students in the Arts. Educational Leadership, 70, 16-21.

Shettle, C., Roey, S., Mordica, J., Perkins, R., Nord, C., Teodorovic, J., Lyons, M., Averett, C., Kastberg, D., \& Brown, J. (2007). The Nation's Report Card [TM]: America's High School Graduates. National Center for Education Statistics, NCES 2007-467, Washington DC: US Department of Education.

Simard, C., Henderson, A. D., Gilmartin, S. K., Schiebinger, L., \& Whitney, T. (2008). Climbing the Technical Ladder: Ob- 
stacles and Solutions for Mid-Level Women in Technology. Stanford, CA: Michelle R. Clayman Institute for Gender Research, Stanford University, and Anita Borg Institute for Women and Technology.

Singer, D. G., \& Singer, J. L. (2006). Fantasy and Imagination. In D. P. Fromberg, \& D. Bergen (Eds.), Play from Birth to 12 : Contexts, Perspectives, and Meanings (pp. 371-378). New York: Routledge.

Sorby, S. A. (2009). Educational Research in Developing 3-D Spatial Skills for Engineering Students. International Journal of Science Education, 31, 459-480. http://dx.doi.org/10.1080/09500690802595839

Sorby, S. A., \& Baartmans, B. J. (2000). The Development and Assessment of a Course for Enhancing the 3-D Spatial Visualization Skills of First Year Engineering Students. Journal of Engineering Education, 89, 301-307. http://dx.doi.org/10.1002/j.2168-9830.2000.tb00529.x

Spohn, C. (2008). Teacher Perspectives on No Child Left Behind and Arts Education: A Case Study. Arts Education Policy Review, 109, 3-12. http://dx.doi.org/10.3200/AEPR.109.4.3-12

Voyer, D., Voyer, S., \& Bryden, M. P. (1995). Magnitude of Sex Differences in Spatial Abilities: A Meta-Analysis and Consideration of Critical Variables. Psychological Bulletin, 117, 250-270. http://dx.doi.org/10.1037/0033-2909.117.2.250 
Scientific Research Publishing (SCIRP) is one of the largest Open Access journal publishers. It is currently publishing more than 200 open access, online, peer-reviewed journals covering a wide range of academic disciplines. SCIRP serves the worldwide academic communities and contributes to the progress and application of science with its publication.

Other selected journals from SCIRP are listed as below. Submit your manuscript to us via either submit@scirp.org or Online Submission Portal.
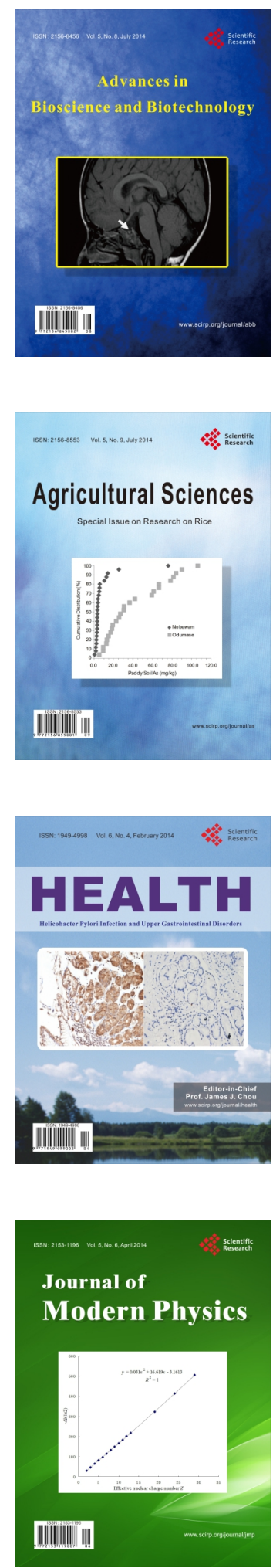
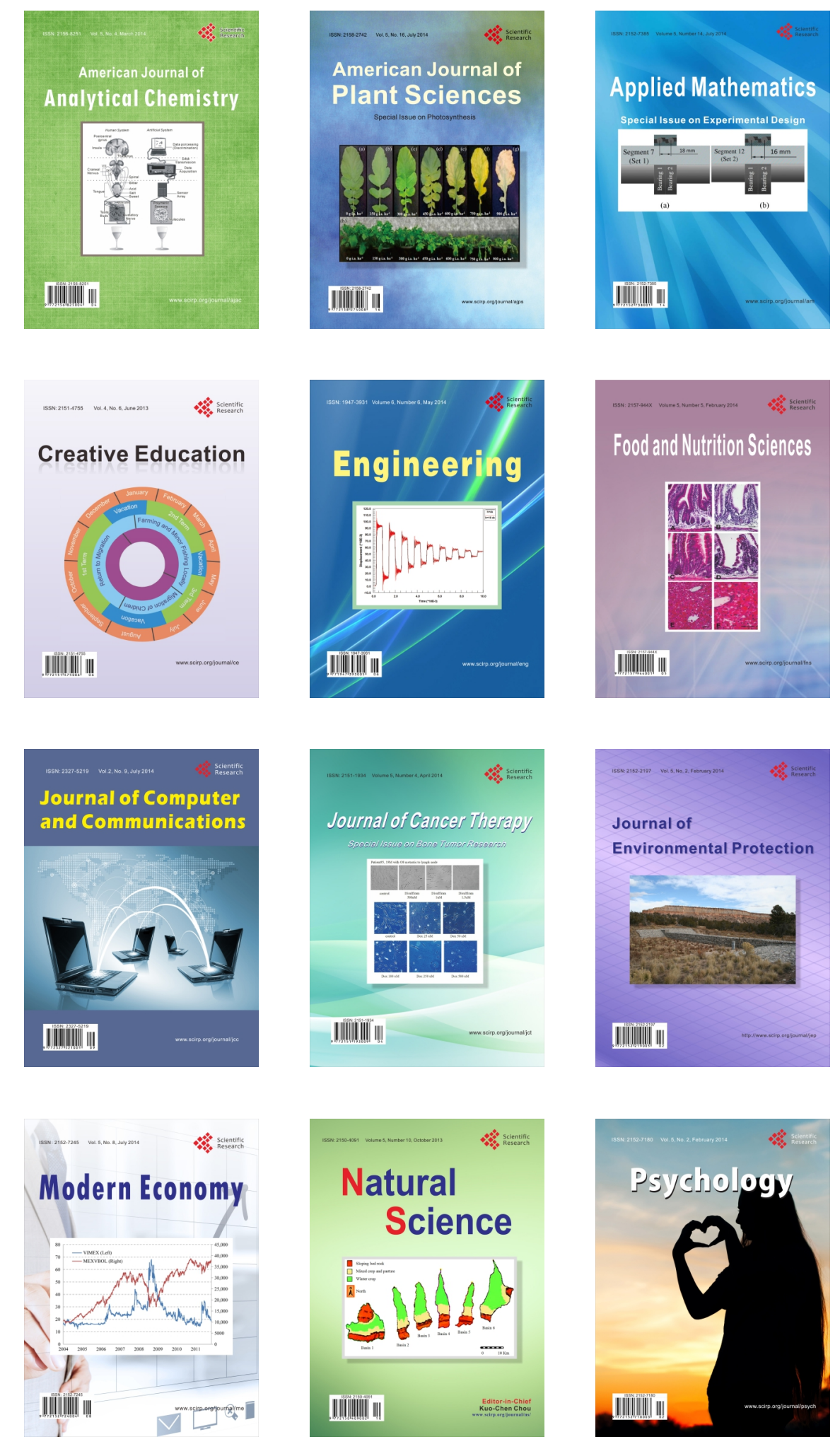